\title{
Phytate and phosphorus utilization by broiler chickens and laying hens fed maize-based diets
}

\author{
Qiugang MA ${ }^{1}$, Markus RODEHUTSCORD $(\bowtie)^{2}$, Moritz NOVOTNY ${ }^{2}$, Lan LI ${ }^{1}$, Luqing YANG ${ }^{1}$ \\ 1 State Key Laboratory of Animal Nutrition, China Agricultural University, Beijing 100193, China \\ 2 Institute of Animal Science, University of Hohenheim, 70599 Stuttgart, Germany
}

\begin{abstract}
Maize grain is primarily used as an energy source for poultry and other animals. Maize has relatively high phytate-P content and very low intrinsic phytase activity. Given that feed phosphates are produced from finite rock phosphate resources, a reduction in the use of feed phosphates in maize-based diets by increasing the utilization of plant $\mathrm{P}$ sources by animals is necessary to make poultry meat and egg production more sustainable. The utilization of $\mathrm{P}$ by poultry is affected by two intrinsic characteristics of maize: the concentration of inositol phosphates and the activity of the intrinsic phytase of the grain in the digestive tract. The objective of this review is to present data on the variation that exists in composition of maize relevant for $\mathrm{P}$ use and to address factors that influence $\mathrm{P}$ utilization in maize-based diets of poultry. Broiler chickens and laying hens have the potential to degrade phytate in the gastrointestinal tract, but this is depressed by high dietary $\mathrm{Ca}$ and $\mathrm{P}$ concentrations. Published values of phytate degradation in broilers are overall higher than those in laying hens. Differences also exist between broiler chickens and growing turkeys and Pekin ducks. The exogenous supplementation of microbial phytases and the introduction of transgenic high phytase maize in poultry diets are efficient not only for the improvement of phytate-P digestibility, production performance, egg quality and bone mineralization, but also for the reduction of $\mathrm{P}$ excreta to control environmental impact.
\end{abstract}

Keywords broiler, ducks, high phytase maize, laying hens, low phytate maize, phytase, turkeys

\section{Introduction}

Maize grain is one of the most important feedstuffs used in the poultry industry throughout the world. Maize is

Received May 20, 2019; accepted July 23, 2019

Correspondence: inst450@uni-hohenheim.de primarily used as an energy source for animals because it has a high concentration of starch that is almost completely digestible $^{[1]}$ and a low concentration of non-starch polysaccharides. Maize also contains minerals such as $\mathrm{P}$ and $\mathrm{Ca}$, which contributes to provide the animal with these essential nutrients.

Animals have a $\mathrm{P}$ requirement that is determined by skeletal growth and other physiologic processes such as energy metabolism or nucleic acid formation. Diets for non-ruminant animals are often supplemented with mineral feed phosphates because the amount of bioavailable $\mathrm{P}$ provided by maize and other plant-based feed ingredients is presumed to be insufficient. However, because feed phosphates are produced from finite rock phosphate resources, a reduction in the use of feed phosphates by increasing the animals' utilization of plant $\mathrm{P}$ sources is necessary to make poultry meat and egg production more sustainable.

The utilization of $\mathrm{P}$ by poultry is affected by two intrinsic characteristics of maize: The concentration of inositol phosphates (InsP) and the activity of the grain enzyme phytase in the digestive tract. Additionally, $\mathrm{P}$ utilization depends on what other feed ingredients and feed additives are used together with maize in the complete diet. The objective of this review is to present data on the variation in the composition of maize relevant for $\mathrm{P}$ utilization by poultry and to address factors that influence this $\mathrm{P}$ utilization in maize-based diets. Given that conditions are different for growing broiler chickens and laying hens, each category is addressed in different sections. Differences between broiler chickens and growing turkeys and Pekin ducks will also be summarized.

\section{Phytate, phosphorus and phytase in maize}

\subsection{Non-transgenic maize}

In non-transgenic genotypes, the total $\mathrm{P}$ concentration is 
around $3 \mathrm{~g} \cdot \mathrm{kg}^{-1}$. In a set of 27 maize samples that contained common hybrids as well as specialty maize with high oil content, the mean total $\mathrm{P}$ concentration was $3.2 \mathrm{~g} \cdot \mathrm{kg}^{-1}$ dry matter (DM) and about $70 \%$ of it was present in the form of myo-inositol 1,2,3,4,5,6-hexakis (dihydrogen phosphate) $\left(\operatorname{InsP}_{6}\right)^{[2]}$. In this sample set, inositol pentaphosphates and other lower InsP isomers were only found in trace amounts. The variation of total $\mathrm{P}$ concentration among the 27 samples was high and values ranged from 2.6 to $4.0 \mathrm{~g} \cdot \mathrm{kg}^{-1} \mathrm{DM}$. The variation in total $\mathrm{P}$ concentration was mainly caused by variation in $\mathrm{InsP}_{6}-\mathrm{P}$ (Fig. 1). The slope of the regression line in this figure indicates that with each $1 \mathrm{~g}$ increment in $\mathrm{InsP}_{6}-\mathrm{P}$ only 0.17 $\mathrm{g}$ of nonphytate $\mathrm{P}$ was deposited in the grain.

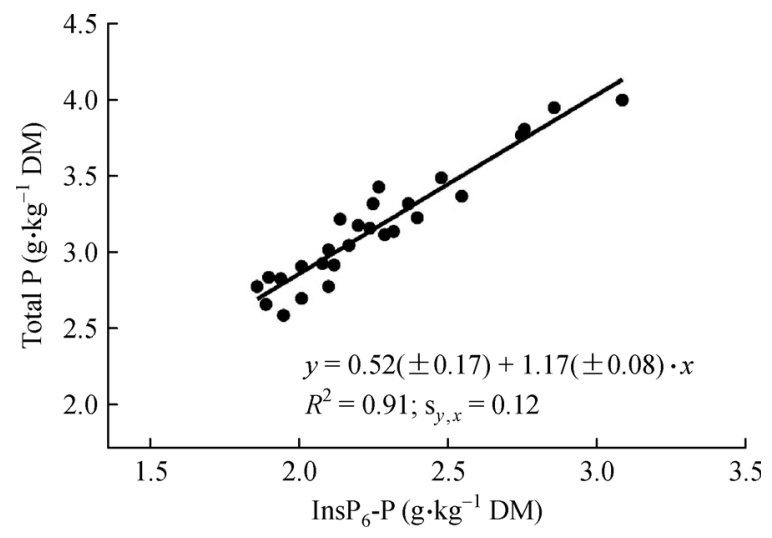

Fig. 1 Relationship between concentrations of total $\mathrm{P}$ and $\operatorname{InsP}_{6}$ $\mathrm{P}$ in 27 maize samples that comprised common hybrids as well as specialty maize with high oil content. Data from Rodehutscord et al. ${ }^{[2]}$.

In the ripening process, cereals accumulate $\operatorname{InsP}_{6}$ in globoids which are located in protein storage vacuoles. In contrast to other cereals that have the globoids mainly associated with the aleurone layer, maize has most of its InsP $_{6}$ located in the germ ${ }^{[3,4]}$. Consistently with this collocation, there is a loose positive relationship between the concentration of $\mathrm{InsP}_{6}-\mathrm{P}$ and crude fat as well as crude protein (Fig. 2) ${ }^{[2]}$, the latter two being interlinked. Given the sample pool of this study contained specialty maize bred for high oil content, maximum concentrations of $123 \mathrm{~g} \cdot \mathrm{kg}^{-1} \mathrm{DM}$ crude fat and $112 \mathrm{~g} \cdot \mathrm{kg}^{-1} \mathrm{DM}$ crude protein were reached. The $\mathrm{Ca}$ concentration overall was low $\left(0.04 \mathrm{~g} \cdot \mathrm{kg}^{-1} \mathrm{DM}\right)$ and not related to $\mathrm{InsP}_{6}-\mathrm{P}$ or total P.

Non-transgenic maize grain is not commonly considered to contain intrinsic phytase activity. Phytase activity often is below the limit of detection, but assay and processing (e.g., heat) conditions affect the determined phytase activity. In a set of 27 maize hybrids, phytase activity ranged between 100 and 190 units $\cdot \mathrm{kg}^{-1} \mathrm{DM}$ when the direct incubation method ${ }^{[5]}$ was used $^{[2]}$.

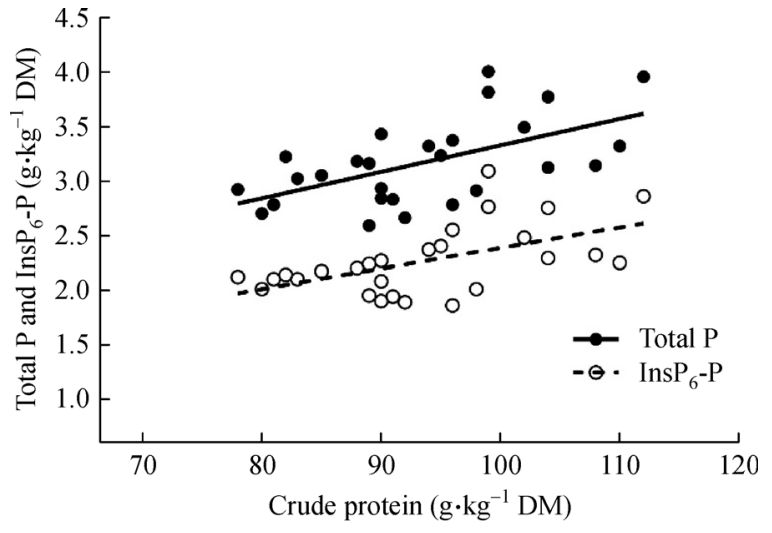

Fig. 2 Relationship between concentrations of crude protein, total $\mathrm{P}$ and $\mathrm{InsP}_{6}-\mathrm{P}$ in the 27 maize hybrids of the GrainUp project. Data from Rodehutscord et al. ${ }^{[2]}$.

\subsection{Low phytate maize}

Approaches to increase $\mathrm{P}$ utilization by animals include maize breeding for low phytate content ${ }^{[6]}$. In the study of Huff et al. ${ }^{[6]}$, the phytate-P concentration was $1.0 \mathrm{~g} \cdot \mathrm{kg}^{-1}$ in the low phytate maize while it was $2.0 \mathrm{~g} \cdot \mathrm{kg}^{-1}$ in normal maize. However, total $\mathrm{P}$ concentrations were higher in the low phytate maize $\left(2.7 \mathrm{~g} \cdot \mathrm{kg}^{-1} \mathrm{vs} 2.3 \mathrm{~g} \cdot \mathrm{kg}^{-1}\right)$. Low phytate maize used in other studies also contained about $1.0 \mathrm{~g} \cdot \mathrm{kg}^{-1}$ less phytate $\mathrm{P}$ than normal maize, often associated with higher total $\mathrm{P}$ concentrations ${ }^{[7-10]}$.

In a broiler chicken assay using tibia ash, relative $\mathrm{P}$ bioavailability ranged from $21 \%$ to $40 \%$ in normal maize and from $59 \%$ to $95 \%$ in low phytate maize ${ }^{[7]}$. Other studies using similar or other approaches in broiler chickens also showed that $\mathrm{P}$ utilization was higher when low phytate maize was used in comparison with normal maize hybrids ${ }^{[9,11,12]}$. Results from a laying hen study also indicated that the $\mathrm{P}$ utilization from low phytate maize is higher than from normal maize ${ }^{[8]}$. Comparative studies were also conducted using byproducts of maize processing. In maize gluten feed and based on bone ash responses in broilers, the relative bioavailability of $\mathrm{P}$ was $46 \%$ when the source was a common hybrid maize but $90 \%$ when the source was a high oil, low phytate maize $^{[13]}$.

\subsection{High phytase maize}

An alternative way to increase $P$ utilization of animals is to develop maize cultivars with high phytase activity through transgenic technology. The overexpression of the Aspergillus niger gene, phyA2, in maize seeds was achieved by using a construct driven by the maize embryo-specific globulin-1 promoter ${ }^{[14]}$. In that study, phytase activity in transgenic inbred-line maize seeds reached about 
12200 units $\cdot \mathrm{kg}^{-1}$, about a 50 -fold increase compared to non-transgenic maize seeds. In another study, the phytase activity of a high phytase hybrid maize seed was up to 8047 phytase units (FTU) $\mathrm{kg}^{-1} \mathrm{DM}$, about a 217 -fold increase compared to the near-isogenic material ${ }^{[15]}$. The total $\mathrm{P}$ concentration was the same $\left(3.3 \mathrm{~g} \cdot \mathrm{kg}^{-1}\right)$ in the high phytase hybrid maize and the near-isogenic material. However, the $\mathrm{P}$ utilization of roosters fed high phytase hybrid maize was greater (56\% vs $38 \%$ ) and the available $P$ content was $46 \%$ higher ( $0.19 \%$ vs $0.13 \%$ on DM basis). No difference was observed in the metabolizable energy and amino acid availability values between the material. There was no difference in $\mathrm{P}$ utilization between roosters fed high phytase hybrid maize and an exogenous microbial phytase product equivalent in phytase activity of the maize-soybean meal-based diets (maize:soybean meal = 2.5:1) $)^{[15]}$.

Some experiments were conducted to assess the effects of long-term feeding of hens with high phytase transgenic maize ${ }^{[16,17]}$. The laying performance and egg quality ${ }^{[16]}$, relative organ weight and serum biochemical traits ${ }^{[17]}$ of the hens fed diets containing high phytase transgenic maize was similar to that of hens fed diets formulated with non-transgenic maize. There was no evidence of translocation of the phyA2 gene or its protein to the blood and visceral tissues ${ }^{[16]}$, muscle tissues and reproductive $\operatorname{organs}^{[17]}$, or eggs ${ }^{[16]}$ of laying hens. Another experiment was conducted to investigate the effect of high phytase transgenic maize on intestinal microbiota, and the fate of transgenic DNA and protein in the digesta and tissues of broilers ${ }^{[18]}$. No adverse effects were found on the quantity and diversity of gut microorganisms, and transgenic phyA2 DNA or protein was also confirmed to be rapidly degraded in the intestinal tract and was not transferred to the tissues of broilers.

\section{Phosphorus utilization in broiler chickens fed maize-based diets}

When feeding broiler chickens, maize is not used as the sole feedstuff but it is mixed with protein feeds and other feeds in various proportions. Common protein feeds, such as soybean meal, rapeseed meal and sunflower meal, are rich in phytate and most of the mixed feeds used in broiler nutrition contain $2.2-2.8 \mathrm{~g} \cdot \mathrm{kg}^{-1} \operatorname{InsP}_{6}-\mathrm{P}$. The animal can metabolize this $\mathrm{P}$ only after it has been released from the myo-inositol ring and absorbed in the intestine. Dephosphorylation is a critical part of the $\mathrm{P}$ utilization process because it needs enzymes such as phytase and other phosphatases. This section gives an overview of $\operatorname{InsP}_{6}$ dephosphorylation in broilers when fed maize-based diets and factors that affect it. Most of the recent studies focused on prececal processes, meaning that measurements were made at the end of the small intestine and refer to the sum of digestive processes occurring to that point.
3.1 Potential of gastrointestinal phytate degradation in broiler chickens

The results from several experiments have revealed that prececal disappearance of $\operatorname{InsP}_{6}$ (meaning that at a minimum one phosphate group was released) in broilers that were provided maize-based diets ranged from $62 \%$ to $89 \%{ }^{[19]}$. This appears to be a remarkably high range when it is considered that the diets did not contain detectable intrinsic phytase activity. It contradicts textbook statements that claim phytate $\mathrm{P}$ is unavailable to poultry. The origin of enzymes that enabled the $\operatorname{InsP}_{6}$ disappearance to such extent was not clarified. It is likely to have been a combination of endogenous enzymes that originate from the intestinal epithelia and from the microbiota colonizing the digestive tract. Some microorganisms potentially can contribute to dephosphorylation ${ }^{[20-22]}$. Microbial diversity is much higher in the cecum than in the more anterior sections of the digestive tract ${ }^{[23]}$ and very high $\operatorname{Ins}_{6}$ disappearance was measured in cecal content ${ }^{[24]}$. However, consistent effects of dietary $\mathrm{P}, \mathrm{Ca}$ and phytase concentrations on gastrointestinal microbiota composition and their role in $\mathrm{InsP}_{6}$ dephosphorylation have not been established, and research in composition and functionality of microbiota in this field is still in an early stage ${ }^{[25-27]}$.

Dephosphorylating enzymes have repeatedly been found in purified brush border membrane vesicles from the small intestine of broiler chickens and laying hens, but their quantitative relevance for $\mathrm{InsP}_{6}$ degradation is hard to calculate. Phytase activity was highest in preparations from the duodenum and lower in the distal part of the ileum ${ }^{[28]}$. It appeared to be reduced with higher phosphate concentration in the intestinal lumen ${ }^{[29]}$ or when diets contained an additional $\mathrm{Ca}$ supplement ${ }^{[30]}$. In a recent study, prececal $\mathrm{InsP}_{6}$ disappearance was $42 \%$ in gnotobiotic broilers fed maize-based diets ${ }^{[31]}$. The authors of this study concluded that mucosa-derived phytases and other phosphatases can contribute substantially to $\mathrm{InsP}_{6}$ degradation.

\subsection{Effects of $\mathrm{P}$ and $\mathrm{Ca}$ supplements on phytate degradation in broiler chickens}

It is important to note that the potential for phytate degradation in the digestive tract mentioned above only occurs under conditions of low P and Ca supply. When mineral $\mathrm{P}$ is added to the diet, which is very common in the poultry industry, endogenous $\operatorname{Ins}_{6}$ degradation in broilers is strongly reduced, an effect even more pronounced when $\mathrm{Ca}$ is included in the supplement and especially when $\mathrm{Ca}$ is supplemented in excess of requirements. The literature in this field has recently been reviewed elsewhere ${ }^{[19]}$, and the reader is referred to this reference for more detailed information.

When broilers were fed diets containing different maize genotypes, the prececal degradation of $\mathrm{InsP}_{6}$ and the 
prececal $\mathrm{P}$ digestibility were lower when maize contained more $\operatorname{InsP}_{6}$ (Fig. 3) ${ }^{[32]}$. Given the location of $\operatorname{InsP}_{6}$ in the germ, crude fat content was also different in that study, making it difficult to unravel the causal relationships between $\mathrm{Ins}_{6}$ content of maize and gastrointestinal Ins $\mathrm{P}_{6}$ degradation. Consistent with these differences in prececal Ins $\mathrm{P}_{6}$ degradation, $\mathrm{P}$ retention efficiency was lower when maize with higher concentrations of $\operatorname{InsP}_{6}$ was used in the diets of broilers ${ }^{[33]}$.

\section{Phosphorus utilization in laying hens fed maize-based diets}

4.1 Potential of gastrointestinal phytate degradation in laying hens

The age of laying hens is a factor influencing gastrointestinal phytate degradation. A study was conducted to determine the availability of phytate $\mathrm{P}$ in 20-week-old and 47-week-old ISA Brown hens fed a maize-soybean meal $\operatorname{diet}^{[34]}$. These authors found that the availability of phytate $\mathrm{P}$ was higher in 47-week-old (53\%) than in 20-week-old (24\%) hens, and that the excreta of the older hens contained less phytate $\mathrm{P}$ than that of the younger hens $\left(3.1 \mathrm{mg} \cdot \mathrm{g}^{-1} \mathrm{DM}\right.$ vs $\left.4.5 \mathrm{mg} \cdot \mathrm{g}^{-1} \mathrm{DM}\right)$, with the proportion of phytate $\mathrm{P}$ in the total fecal P being $15 \%$ and $24 \%$, respectively. Consistent with these differences, the in vitro phytase activity in the stomach, intestinal mucosa and cecum was higher in the 47-week-old hens than in the 20week-old hens. A more recent study also found that the $\mathrm{P}$ digestibility from canola meal for Hy-Line Brown laying hens at the age of 32 weeks was higher than that of pullets at 17 weeks of age $(32.2 \% \text { vs } 22.9 \%)^{[35]}$. The authors suggested this difference was caused by a longer retention time of digesta in the digestive tract of the hens, the maturation of digestive functions, lower endogenous $\mathrm{P}$ loss (344 mg $\cdot \mathrm{kg}^{-1}$ vs $493 \mathrm{mg} \cdot \mathrm{kg}^{-1}$ DM intake) and the higher metabolic demand due to eggshell formation.
4.2 Effects of $\mathrm{Ca}$ supplements on phytate degradation in laying hens

The $\mathrm{P}$ availabilities reported from the laying hen studies cited above ranged from $23 \%$ to $53 \%$, which was much lower than $\mathrm{InsP}_{6}$ degradation in broilers $(62 \%-89 \%)^{[19]}$. This difference is partly due to the higher $\mathrm{Ca}$ content in the feed (33-45 $\mathrm{g} \cdot \mathrm{kg}^{-1}$ for laying hens vs $0.8-1.0 \mathrm{~g} \cdot \mathrm{kg}^{-1}$ for broilers) and the higher ratio between $\mathrm{Ca}$ and $\mathrm{P}$ (5.5-7.5 for laying hens vs $1.3-1.5$ for broilers). The poor availability of phytate $\mathrm{P}$ in laying hens may not be a consequence of digestive insufficiency, but rather of the simultaneous ingestion of phytate with high amounts of $\mathrm{Ca}$ from mineral phosphate sources and limestone. Given the P utilizations has been confirmed to decrease with increasing levels of $\mathrm{Ca}^{[36,37]}$, excess supply of $\mathrm{Ca}$ should be avoided. Spatial separation of limestone from the remainder of the diet of broilers has been shown to be an effective way to enhance the solubility and digestibility of phytate $\mathrm{P}$ and amino $\operatorname{acids}^{[38]}$. However, the effectiveness of limestone spatial separation in laying hens has not been investigated.

\subsection{Effects of intrinsic and exogenous phytase on phytate degradation in laying hens}

Single feeds such as barley, field bean, maize, rapeseed press cake, rapeseed meal, rye, sunflower, triticale and wheat have been found to have different $\mathrm{P}$ utilization in laying hens (wheat $47.4 \%$, barley $34.3 \%$, triticale $34.0 \%$, rye $30.1 \%$, rapeseed meal $27.7 \%$, field bean $23.6 \%$, rapeseed press cake $22.0 \%$, oats $19.5 \%$, maize $19.0 \%$ and sunflower $10.0 \%$ ). The correlation between intrinsic phytase activity and $\mathrm{P}$ utilization in the different feeds (except rye and triticale) was statistically significant with $r=0.88^{[39]}$.

The efficacy of exogenous microbial phytase in maizesoybean meal-based diets for laying hens could be evaluated through long-term feeding experiments or short-term digestibility studies. For example, it was

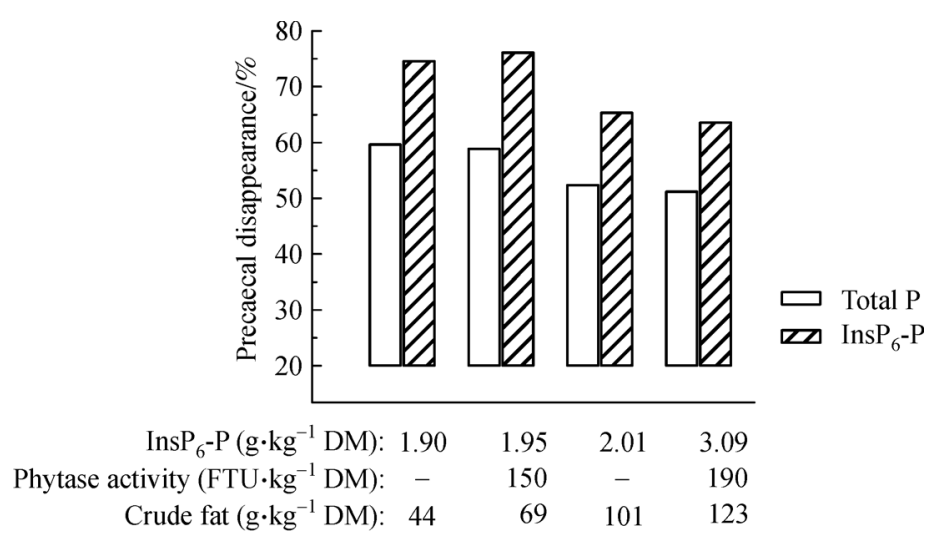

Fig. 3 Disappearance of total $\mathrm{P}$ and $\mathrm{Ins}_{6}-\mathrm{P}$ by the end of the ileum in broiler chickens fed maize-based diets containing maize genotypes with different concentrations of $\operatorname{Ins}_{6}-\mathrm{P}$, crude fat and intrinsic phytase activity. Data from Ingelmann et al. ${ }^{[32]}$. 
shown that $250 \mathrm{FTU} \cdot \mathrm{kg}^{-1}$ diet hydrolyzed an amount of phytate $\mathrm{P}$ that was equivalent to $1.3 \mathrm{~g} \mathrm{P}$ from monocalcium phosphate $^{[40]}$. The phytate degradation of exogenous microbial phytase was affected by dietary $\mathrm{Ca}$ concentrations. The prececal phytate degradation in a diet with $40 \mathrm{~g} \cdot \mathrm{kg}^{-1} \mathrm{Ca}$ was significantly reduced (48\%-36\%) compared to that in a diet with $30 \mathrm{~g} \cdot \mathrm{kg}^{-1} \mathrm{Ca}^{[40]}$.

In another study, with the addition of $300 \mathrm{FTU} \cdot \mathrm{kg}^{-1}$ to the feed, the phytate-P degradation in soybean meal, maize and rice bran increased from 26\%, 23\% and 36\% to $62 \%, 52 \%$ and $51 \%$, respectively ${ }^{[41]}$. The $\mathrm{P}$ utilization of these three feeds increased from 37\%, 29\% and 36\% to $53 \%, 45 \%$ and $43 \%$, respectively. Although less than $500 \mathrm{FTU} \cdot \mathrm{kg}^{-1}$ phytase in the diet of laying hens was considered sufficient to degrade phytate, supplementation up to $5000 \mathrm{FTU} \cdot \mathrm{kg}^{-1}$ phytase in diet could further increase the phytate-P degradation ${ }^{[42]}$ (Fig. 4).

The phytate degradation occurs mainly from crop to ileum, and the residual phytate-P content decreases caudally along the gastrointestinal tract of hens ${ }^{[42]}$. The phytase expressed in transgenic high phytase maize was as efficacious as the commercial microbial phytases in Pdeficient diets for the improvement of phytate-P degradation (Fig. 4), laying performance, egg quality and bone mineralization $^{[43]}$.

\section{Differences between broiler chickens, Pekin ducks and turkeys}

Feed compounding for growing poultry species other than broiler chickens usually presumes that $\mathrm{P}$ utilization does not vary by species. This assumption is most likely the consequence of limited data available for growing turkeys and ducks. However, an increasing number of studies indicate that differences in gastrointestinal phytate degradation and $\mathrm{P}$ utilization exist between species.

When using a low-P basal diet and diets containing graded levels of monobasic calcium phosphate, $\mathrm{P}$ utilization of the basal diet was higher in broiler chickens than turkeys and Pekin ducks, but utilization of mineral $\mathrm{P}$ was highest in Pekin ducks, followed by turkeys and broiler chickens, respectively ${ }^{[44]}$. Other experiments confirmed that $\mathrm{P}$ utilization by Pekin ducks fed feeds with different phosphates is high $^{[45]}$. It is remarkable that species differences are in the opposite direction, depending on whether plant $\mathrm{P}$ or mineral $\mathrm{P}$ is investigated. The crop plays some role in microbial enzyme production in broiler chickens and it may be speculated whether the absence of a fully functioning crop in ducks is the reason for lower phytate-P utilization in ducks compared to broiler chickens. If $\mathrm{InsP}_{6}$ degradation is lower in Pekin ducks than

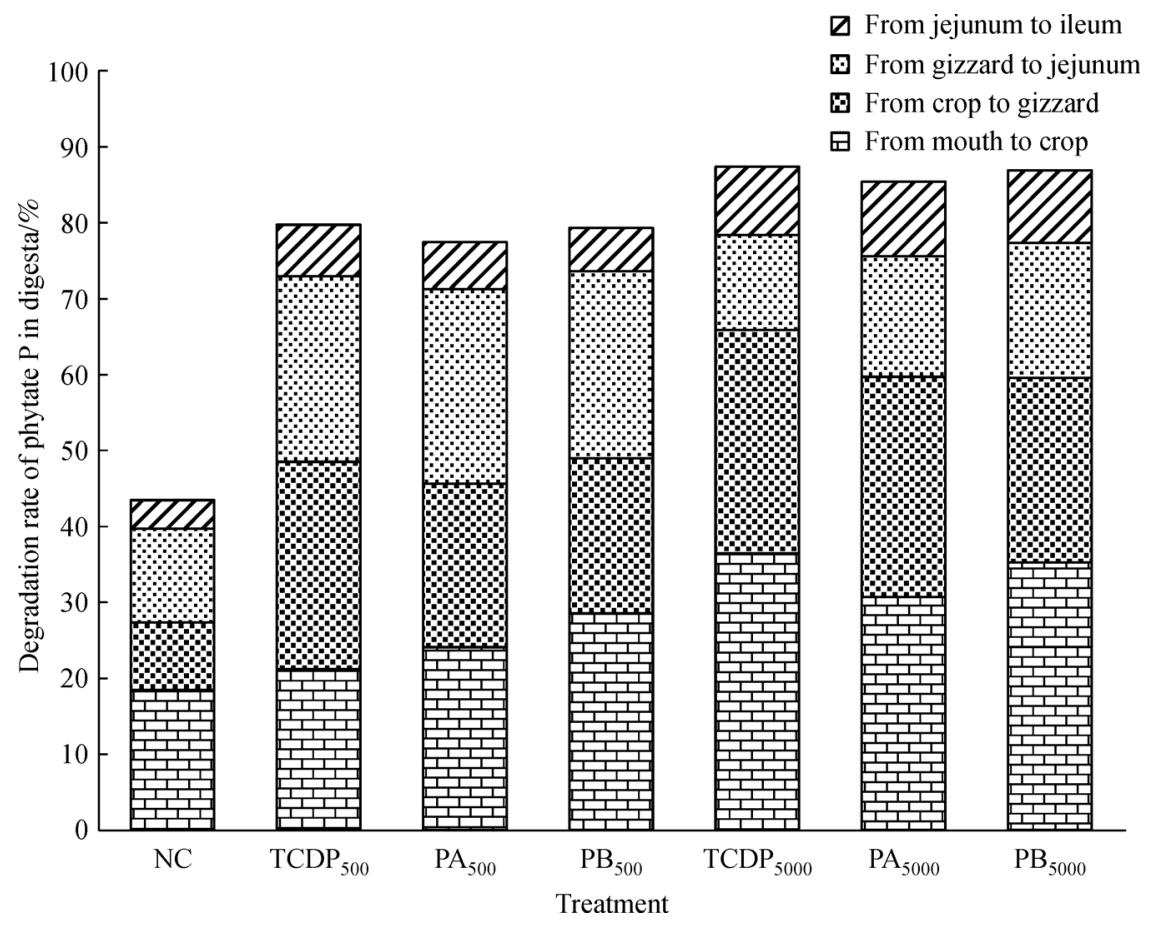

Fig. 4 Degradation rate (\%) of phytate $\mathrm{P}$ in digesta of laying hens fed with or without added phytase from various sources. $\mathrm{NC}=$ negative control diet; $\mathrm{TCDP}_{500}=$ transgenic maize-derived phytase at $500 \mathrm{FTU} \cdot \mathrm{kg}^{-1}$ of diet; $\mathrm{PA}_{500}=$ commercial phytase source A (Natuphos, BASF AG, Ludwigshafen, Germany) at $500 \mathrm{FTU} \cdot \mathrm{kg}^{-1}$ of diet; $\mathrm{PB}_{500}=$ commercial phytase source B (Phyzyme, Danisco Animal Nutrition, Carol Stream, IL, USA) at $500 \mathrm{FTU} \cdot \mathrm{kg}^{-1}$ of diet; $\mathrm{TCDP}_{5000}=\operatorname{transgenic~maize-derived~phytase~at~} 5000 \mathrm{FTU} \cdot \mathrm{kg}^{-1}$ of diet; $\mathrm{PA}_{5000}=$ commercial phytase source $\mathrm{A}$ at $5000 \mathrm{FTU} \cdot \mathrm{kg}^{-1}$ of diet; $\mathrm{PB}_{5000}=$ commercial phytase source $\mathrm{B}$ at $5000 \mathrm{FTU} \cdot \mathrm{kg}^{-1}$ of diet. One phytase activity unit (FTU) is defined as the quantity of enzyme that releases $1 \mu \mathrm{mol}$ of inorganic $\mathrm{P}$ per minute from $1.5 \mathrm{mmol} \cdot \mathrm{L}^{-1}$ sodium phytate at $\mathrm{pH} 5.5$ at $37^{\circ} \mathrm{C}$. Reprinted from Gao et al. ${ }^{[42]}$, with permission from Oxford University Press. 
broiler chickens, this might mean that the diminishing effects of mineral $\mathrm{P}$ supplements on $\mathrm{Ins}_{6}$ degradation (chapter 3.2) are less pronounced in ducks than broiler chickens. Such effects may help to explain the differences in calculated digestibility of mineral $\mathrm{P}$ sources between poultry species.

In young turkeys, $\mathrm{P}$ digestibility and $\mathrm{P}$ retention values of dried distiller's grains with solubles (DDGS) were high in broiler chickens (94\% and $92 \%$ ) but lower in turkeys $(76 \% \text { and } 71 \%)^{[46]}$. Differences in InsP $_{6}$ degradation in the digestive tract and release of phosphate are likely to have contributed to these differences. When providing low-P wheat-soybean meal-based diets to turkeys, $\mathrm{InsP}_{6}$ degradation by the end of the ileum was $29 \%$ in the absence of a phytase supplement and $45 \%$ when $500 \mathrm{FTU} \cdot \mathrm{kg}^{-1}$ of diet was added ${ }^{[47]}$. This level of $\mathrm{InsP}_{6}$ degradation was remarkably lower than that reported above from similar studies with broiler chickens. When using different genotypes of maize in studies with broiler chickens and turkeys with and without a phytase supplement, prececal $\mathrm{InsP}_{6}$ degradation was much lower in the turkey study than in the broiler study, irrespective of phytase addition ${ }^{[32]}$. Endogenous mucosal phytase activity was detected in the small intestine of broiler chickens ${ }^{[28,29]}$ and it cannot be ruled out that this activity is different in young turkeys, leading to differences in phosphate release from InsP ${ }_{6}$. Other variables such as passage rate and $\mathrm{pH}$ in different sections of the digestive tract can also contribute to the differences between species. However, any hypotheses derived from the thoughts on causal relationships presented here need to be tested in experiments that involve measurements of $\operatorname{InsP}_{6}$ degradation, mucosal phytase activity, and microbiota composition and functionality in different sections of the gastrointestinal tract of the different species.

\section{Conclusions}

Common maize hybrids have a relatively high proportion of $\mathrm{P}$ bound as phytate $\mathrm{P}$ and a very low intrinsic phytase activity. The cultivation of low phytate or transgenic high phytase maize cultivars could be a way to increase $P$ utilization by animals. Broiler chickens and laying hens have the potential of gastrointestinal phytate degradation, but this is depressed by high dietary $\mathrm{Ca}$ and $\mathrm{P}$ concentrations, and other factors. The published values of phytate degradation in broilers are normally higher than those in laying hens. Differences in $\mathrm{P}$ utilization and phytate degradation exist between broilers, turkeys and Pekin ducks. The exogenous supplementation of microbial phytases and the introduction of transgenic high phytase maize in poultry diets are efficient not only for the improvement of phytate-P digestibility, production performance, egg quality and bone mineralization, but also for the reduction of $\mathrm{P}$ excreta to control environmental pollution.

Acknowledgements This work was undertaken within the framework of the International Research Training Group "Adaptation of maize-based food-feed-energy systems to limited phosphate resources" funded by the Deutsche Forschungsgemeinschaft (DFG, German Research Foundation) 328017493/GRK 2366. Moritz Novotny was funded by this project. The work in China was financially supported by the National Natural Science Foundation of China (31772621) and China Agricultural Research System program (CARS-40-K08). Lan Li was also partly founded by Postgraduate International Training and Promotion Project of China Agricultural University.

Compliance with ethics guidelines Qiugang Ma, Markus Rodehutscord, Moritz Novotny, Lan Li, and Luqing Yang declare that they have no conflicts of interest or financial conflicts to disclose.

This article is a review and does not contain any studies with human or animal subjects performed by any of the authors.

\section{References}

1. Weurding R E, Veldman A, Veen W A G, van der Aar P J, Verstegen $\mathrm{M}$ W A. Starch digestion rate in the small intestine of broiler chickens differs among feedstuffs. Journal of Nutrition, 2001, 131 (9): 2329-2335

2. Rodehutscord M, Rückert C, Maurer H P, Schenkel H, Schipprack W, Bach Knudsen K E, Schollenberger M, Laux M, Eklund M, Siegert W, Mosenthin R. Variation in chemical composition and physical characteristics of cereal grains from different genotypes. Archives of Animal Nutrition, 2016, 70(2): 87-107

3. O'Dell B L, de Boland A. Complexation of phytate with proteins and cations in corn germ and oilseed meals. Journal of Agricultural and Food Chemistry, 1976, 24(4): 804-808

4. Lin L, Ockenden I, Lott J N A. The concentrations and distribution of phytic acid-phosphorus and other mineral nutrients in wild-type and low phytic acid1-1 (1pa1-1) corn (Zea mays L.) grains and grain parts. Canadian Journal of Botany, 2005, 83(1): 131-141

5. Greiner R, Egli I. Determination of the activity of acidic phytatedegrading enzymes in cereal seeds. Journal of Agricultural and Food Chemistry, 2003, 51(4): 847-850

6. Huff W E, Moore P A Jr, Waldroup P W, Waldroup A L, Balog J M, Huff G R, Rath N C, Daniel T C, Raboy V. Effect of dietary phytase and high available phosphorus corn on broiler chicken performance. Poultry Science, 1998, 77(12): 1899-1904

7. Douglas M W, Peter C M, Boling S D, Parsons C M, Baker D H. Nutritional evaluation of low phytate and high protein corns. Poultry Science, 2000, 79(11): 1586-1591

8. Snow J L, Douglas M W, Batal A B, Persia M E, Biggs P E, Parsons $\mathrm{C}$ M. Efficacy of high available phosphorus corn in laying hen diets. Poultry Science, 2003, 82(6): 1037-1041

9. Yan F, Kersey J H, Fritts C A, Waldroup P W, Stilborn H L, Crum R C Jr, Rice D W, Raboy V. Evaluation of normal yellow dent corn and high available phosphorus corn in combination with reduced dietary phosphorus and phytase supplementation for broilers grown to market weights in litter pens. Poultry Science, 2000, 79(9): 12821289 
10. Yan F, Waldroup P W. Nonphytate phosphorus requirement and phosphorus excretion of broiler chicks fed diets composed of normal or high available phosphate corn as influenced by phytase supplementation and vitamin D sources. International Journal of Poultry Science, 2006, 5(3): 219-228

11. Li Y C, Ledoux D R, Veum T L, Raboy V, Ertl D S. Effects of low phytic acid corn on phosphorus utilization, performance, and bone mineralization in broiler chicks. Poultry Science, 2000, 79(10): 1444-1450

12. Jang D A, Fadel J G, Klasing K C, Mireles A J Jr, Ernst R A, Young K A, Cook A, Raboy V. Evaluation of low-phytate corn and barley on broiler chick performance. Poultry Science, 2003, 82(12): 19141924

13. Peter C M, Baker D H. Bioavailability of phosphorus in corn gluten feed derived from conventional and low-phytate maize. Animal Feed Science and Technology, 2002, 95(1-2): 63-71

14. Chen R, Xue G, Chen P, Yao B, Yang W, Ma Q, Fan Y, Zhao Z, Tarczynski M C, Shi J. Transgenic maize plants expressing a fungal phytase gene. Transgenic Research, 2008, 17(4): 633-643

15. Gao C Q, Ma Q G, Ji C, Luo X G, Tang H F, Wei Y M. Evaluation of the compositional and nutritional values of phytase transgenic corn to conventional corn in roosters. Poultry Science, 2012, 91(5): 1142-1148

16. Ma Q, Gao C, Zhang J, Zhao L, Hao W, Ji C. Detection of transgenic and endogenous plant DNA fragments and proteins in the digesta, blood, tissues, and eggs of laying hens fed with phytase transgenic corn. PLoS One, 2013, 8(4): e61138

17. Gao C, Ma Q, Zhao L, Zhang J, Ji C. Effect of dietary phytase transgenic corn on physiological characteristics and the fate of recombinant plant DNA in laying hens. Asian-Australasian Journal of Animal Sciences, 2014, 27(1): 77-82

18. Lu L, Guo J, Li S, Li A, Zhang L, Liu Z, Luo X. Influence of phytase transgenic corn on the intestinal microflora and the fate of transgenic DNA and protein in digesta and tissues of broilers. PLoS One, 2015, 10(11): e0143408

19. Rodehutscord M. Advances in understanding the role of phytate in phosphorus and calcium nutrition of poultry, in achieving sustainable production of poultry meat. Volume 2 Breeding and nutrition, Applegate T, Editor. Cambridge: Burleigh Dodds, 2017, 165-180

20. Vats P, Banerjee U C. Production studies and catalytic properties of phytases (myo-inositolhexakisphosphate phosphohydrolases): an overview. Enzyme and Microbial Technology, 2004, 35(1): 314

21. Konietzny U, Greiner R. Molecular and catalytic properties of phytate-degrading enzymes (phytases). International Journal of Food Science \& Technology, 2002, 37(7): 791-812

22. Raghavendra P, Halami P M. Screening, selection and characterization of phytic acid degrading lactic acid bacteria from chicken intestine. International Journal of Food Microbiology, 2009, 133 (1-2): 129-134

23. Witzig M, Carminha-Silva A, Green-Engert R, Hoelzle K, Zeller E, Seifert J, Hoelzle L E, Rodehutscord M. Spatial variation of the gut microbiota in broiler chickens as affected by dietary available phosphorus and assessed by T-RFLP analysis and 454 pyrosequencing. PLoS One, 2015, 10(11): e0143442

24. Zeller E, Schollenberger M, Kühn I, Rodehutscord M. Hydrolysis of phytate and formation of inositol phosphate isomers without or with supplemented phytases in different segments of the digestive tract of broilers. Journal of Nutritional Science, 2015, 4: e1

25. Borda-Molina D, Seifert J, Camarinha-Silva A. Current perspectives of the chicken gastrointestinal tract and its microbiome. Computational and Structural Biotechnology Journal, 2018, 16: 131-139

26. Borda-Molina D, Vital M, Sommerfeld V, Rodehutscord M, Camarinha-Silva A. Insights into broilers' gut microbiota fed with phosphorus, calcium, and phytase supplemented diets. Frontiers in Microbiology, 2016, 7: 2033

27. Borda-Molina D, Zuber T, Siegert W, Camarinha-Silva A, Feuerstein D, Rodehutscord M. Effects of protease and phytase supplements on small intestinal microbiota and amino acid digestibility in broiler chickens. Poultry Science, 2019, 98(7): 2906-2918

28. Maenz D D, Classen H L. Phytase activity in the small intestinal brush border membrane of the chicken. Poultry Science, 1998, 77 (4): 557-563

29. Huber K, Zeller E, Rodehutscord M. Modulation of small intestinal phosphate transporter by dietary supplements of mineral phosphorus and phytase in broilers. Poultry Science, 2015, 94(5): 1009-1017

30. Applegate T J, Angel R, Classen H L. Effect of dietary calcium, 25hydroxycholecalciferol, or bird strain on small intestinal phytase activity in broiler chickens. Poultry Science, 2003, 82(7): 11401148

31. Sommerfeld V, Van Kessel A G, Classen H L, Schollenberger M, Kühn I, Rodehutscord M. Phytate degradation in gnotobiotic broiler chickens and effects of dietary supplements of phosphorus, calcium, and phytase. Poultry Science, 2019: pez309

32. Ingelmann C J, Witzig M, Möhring J, Schollenberger M, Kühn I, Rodehutscord M. Phytate degradation and phosphorus digestibility in broilers and turkeys fed different corn sources with or without added phytase. Poultry Science, 2019, 98(2): 912-922

33. Kasim A B Jr, Edwards H M Jr. Effect of sources of maize and maize particle sizes on the utilization of phytate phosphorus in broiler chicks. Animal Feed Science and Technology, 2000, 86(1-2): $15-26$

34. Marounek M, Skřivan M, Dlouhá G, Břeňová N. Availability of phytate phosphorus and endogenous phytase activity in the digestive tract of laying hens 20 and 47 weeks old. Animal Feed Science and Technology, 2008, 146(3-4): 353-359

35. Verardi A D, Schneider A F, Mayer J K, Yuri F M, Oliveira V, Gewehr C E. True phosphorus digestibility and total endogenous phosphorus losses associated with canola meal for brown laying hens 17 and 32 weeks old. Livestock Science, 2019, 222: 49-53

36. Scheideler S E, Sell J L. Effects of calcium and phase-feeding phosphorus on production traits and phosphorus retention in two strains of laying hens. Poultry Science, 1986, 65(11): 2110-2119

37. Keshavarz K. The effect of dietary levels of calcium and phosphorus on performance and retention of these nutrients by laying hens. Poultry Science, 1986, 65(1): 114-121

38. Wilkinson S J, Selle P H, Bedford M R, Cowieson A J. Separate feeding of calcium improves performance and ileal nutrient digestibility in broiler chicks. Animal Production Science, 2014, 54(2): $172-178$

39. Oloffs K, Cossa J, Jeroch H. Phosphorus utilization from different 
vegetable feedstuffs by laying hens. Archiv für Geflügelkunde, 2000, 64(1): 24-28

40. Van der Klis J D, Versteegh H A J, Simons P C M, Kies A K. The efficacy of phytase in corn-soybean meal-based diets for laying hens. Poultry Science, 1997, 76(11): 1535-1542

41. Leske K L, Coon C N. A bioassay to determine the effect of phytase on phytate phosphorus hydrolysis and total phosphorus retention of feed ingredients as determined with broilers and laying hens. Poultry Science, 1999, 78(8): 1151-1157

42. Gao C Q, Ji C, Zhao L H, Zhang J Y, Ma Q G. Phytase transgenic corn in nutrition of laying hens: residual phytase activity and phytate phosphorus content in the gastrointestinal tract. Poultry Science, 2013, 92(11): 2923-2929

43. Gao C Q, Ji C, Zhang J Y, Zhao L H, Ma Q G. Effect of a novel plant phytase on performance, egg quality, apparent ileal nutrient digestibility and bone mineralization of laying hens fed cornsoybean diets. Animal Feed Science and Technology, 2013, 186(1-
2): 101-105

44. Rodehutscord M, Dieckmann A. Comparative studies with threeweek-old chickens, turkeys, ducks, and quails on the response in phosphorus utilization to a supplementation of monobasic calcium phosphate. Poultry Science, 2005, 84(8): 1252-1260

45. Wendt $P$, Rodehutscord $M$. Investigations on the availability of inorganic phosphate from different sources with growing White Pekin ducks. Poultry Science, 2004, 83(9): 1572-1579

46. Adebiyi A, Olukosi O. Determination in broilers and turkeys of true phosphorus digestibility and retention in wheat distillers dried grains with solubles without or with phytase supplementation. Animal Feed Science and Technology, 2015, 207: 112-119

47. Ingelmann C J, Witzig M, Möhring J, Schollenberger M, Kühn I, Rodehutscord M. Effect of supplemental phytase and xylanase in wheat-based diets on prececal phosphorus digestibility and phytate degradation in young turkeys. Poultry Science, 2018, 97(6): 20112020 